\title{
The Empowerment as Community Learning Based on Ecotourism of Coastal Border at West Kalimantan
}

\author{
Toto Sugito ${ }^{1}$, Adhi Iman Sulaiman ${ }^{1}$, Ahmad Sabiq $^{2}$, Muslih Faozanudin ${ }^{3} \&$ Bambang Kuncoro $^{2}$ \\ ${ }^{1}$ Department of Communication Science, Jenderal Soedirman University, Indonesia \\ ${ }^{2}$ Department of Political Science, Jenderal Soedirman University, Indonesia \\ ${ }^{3}$ Department of Public Adminsitration, Jenderal Soedirman University, Indonesia \\ Correspondence: Toto Sugito, Department of Communication Science, Jenderal Soedirman University, Indonesia.
}

Received: September 7, 2019; Accepted: September 24, 2019; Published: September 28, 2019

\begin{abstract}
Development in coastal border areas is an important priority for addressing social and economic disparities and conflict through empowerment programs. The objective of the research is to analyze the empowerment as community learning based on ecotourism of coastal border. This research uses qualitative method in which Participatory Rural Appraisal (PRA) and data collection is conducted through in-depth interview, observation, documentation analysis, Focus Group Discussion (FGD) and Participatory Decision Making (PDM). The research takes place in the border area of West Kalimantan namely Sebubus Village and Temajuk Village, Paloh Subdistrict, Sambas District. The informants are determined through purposive sampling consisting of empowerment activists, community leaders, village government, business groups, academics, and tourists. Data is analyzed using SWOT analysis. The results show (1) to develop ecotourism potential of mangrove forest and food processing from mangrove fruit, turtle breeding, and coastal tourism, a participatory and sustainable empowerment of community learning program is necessary. (2) Youth figures as community learning activists of ecotourism empowerment along with community leaders need support and cooperation from village and local government, as well as private parties. (3) Temajuk village in particular requires the improvement of road infrastructure, electrical lighting and telecommunication signals in order not to cause social and economic dependency and jealousy with Malaysian border areas.
\end{abstract}

Keywords: coastal border, ecotourism, activist, community learning, empowerment

\section{Introduction}

The West Kalimantan region is nicknamed as the "Thousand Rivers" province because it has hundreds of large and small rivers that are often passed through by sailing boats. This region is bordered by Malaysia's Sarawak state and according to the report of the Directorate General of Development of Disadvantaged Regions in 2017, one of its districts, Sambas is still one of the disadvantaged areas. In addition, Salim (2011) using spatial analysis stated that Sambas District is a region with low human, social and agricultural development level. Sarosa (2011) states that most of the border areas are poor and underdeveloped, but the focus of border area problem is on security. The authors' study in 2018 found that people in the border areas that people in the border areas such as in Sebubus Village and Temajuk Village, Paloh Subdistrict, Sambas District, West Kalimantan, still lack of awareness and ability to cultivate the resources potential of natural resources or the environment, especially plantations, beaches and tourism. Moreover, the infrastructure access such as roads and bridges are poor. If there is rain as we experienced ourselves then people riding vehicles have difficulty to pass the bridge or road where most of the roads are still soil which has not been covered by the asphalt.

One of the main problems in Temajuk Village is infrastructure access of vehicle from the Sekura River Crossing Pier to Sebubus Village. It is paved but badly damaged by heavy trucks carrying oil palm to be sent to processing plants. In addition, from the Ceremai River Crossing Pier to Temajuk Village road access is still in the form of land or not asphalted which resulted in the difficulty of access when it rains. Temajuk village can only be passed in the morning until late afternoon, because at night the road is difficult to pass because no street lighting. However, the current road widening process is still going to be as wide as 10 meters. Meanwhile, the distance from Temajuk to Telok Melano Sarawak Malaysia is closer and better access road compared with the condition from Temajuk Village to Sebubus Village. Telok Melano is about $2 \mathrm{~km}$ from Temajuk while Sebubus is about $40 \mathrm{~km}$ away. In the village of Temajuk access road to the sights especially to Atong Bay is still difficult and very steep and slippery, 
in case of rain. Except, by using a motorcycle that passes the coastal path. Another obstacle is that there is no street lighting, even in Atjoe Bay tourist sites people still rely on generators for lighting.

Apart from all its limitations, Temajuk Village has many tourism potentials, especially its very beautiful and still natural beaches with its white sand, coastal rocks, crystal clear sea water and scenery. It also has the unique culinary potential of fresh fish with many choices in the Camar Bulan fish market which is also the place of interaction and transactions of Melano Sarawak Malaysian community and Temajuk community to trade fish either using ringgit or rupiah. Sometimes Temajuk people often buy daily necessities such as cooking oil, sugar, rice, and gas to Malaysia's Melano region because the price is more affordable and the distance is closer. Therefore, it is interesting to conduct research in Temajuk Village, Paloh Subdistrict, Sambas District, especially about the formulation of community empowerment strategy in coastal border management for social resilience and economic strengthening. As stated by Huruswati el al. (2012) development programs should be more focused on accelerating regional development where social conditions, economic culture, regional finance, accessibility and availability of infrastructure are still lagging behind. Therefore it needs approach or development strategy in order to improve people's welfare. Sutaat (2012) asserted that people who access public services are generally still limited, in addition to the lack of ability to manage agriculture and plantation and the limited physical infrastructure and social welfare problems. Gevisioner et al. (2013) states the development of coastal border areas should use a balanced approach to economic and ecological growth based on the interests and potential of the community.

Rural development becomes the foundation, supporter and determinant of development for the region, urban area, even the nation and the state, because in the rural area lies the reality of community life that has many potentials. It supplies basic needs, from agriculture, plantation, animal husbandry and fishery as well as becomes location of tourism. If the development of the village and its people are not able to empower its potential and increase its productivity there will be problems such as urbanization, unemployment, and poverty, even the village will be abandoned by its people in order to become migrant workers. The spirit of developing the village is a manifestation of the ideal development concepts of participatory, democratic, socio-economic based and sustainable development. According to Handoko, et al. (2013) development in the village is a determinant and very important in determining urban development. Sulaiman et al. (2017) emphasizes that village development is the foundation and determinant of regional and national development successes, as villages have resources that can meet the needs of agriculture, plantation, livestock, fisheries and tourism.

The importance of rural development, including development in border and coastal areas, is one of the most important areas of study and program, especially in the framework of maintaining sovereignty, nationalism and justice by accelerating the distribution and welfare of rural communities. It is important and strategic to develop border areas, because developing border and coastal areas are integral part of national development. Based on Law Number 26 Year 2007 on Spatial Planning, in addition to Government Regulation of Republic Indonesia Number 26 Year 2008 on National Spatial Plan, it is said that the border area is classified as strategic area where spatial arrangement is prioritized in the implementation of development. According to Law No. 6 of 2014 on villages, in Article 13 it is stated that the government can initiate the formation of villages in areas that are specific and strategic for the national interest. The interpretation of the article on "special and strategic areas" refers to the outermost areas of state borders, transmigration programs and other programs that considered strategic. According Patriadi (2010) border areas have their own uniqueness, in terms of geographical, social, and cultural aspects. Thus, the management of border areas requires a comprehensive policy, as it aims to create and enhance economic and trade activities between the two countries and will impact on improving the welfare of local communities and increasing state revenues through export and import activities. The border areas are strategically valuable in the success of national development and improving the socio-economic welfare of surrounding communities.

However, development in the border and coastal areas still has challenges and problem, as stated in the findings of Widiati (2007) that explain the handling of border areas between countries has more problems than the achievement of development progress, there are the gap of facilities and infrastructure between the two countries, land transportation, telecommunications, electricity, information, and other infrastructure.

In addition, the disturbance of bilateral relations on the border is related to security and political aspects as well as violations in the management and exploitation of natural resources across borders on land and sea. Furthermore, based on a review report of the Regional Development Planning Agency (Bappeda) of West Kalimantan in 2016 the border condition has not changed much, especially to compete with the rapid development of border areas from neighboring countries, such as Sarawak Malaysia which is able to build growth centers on the border through various activities such as economic and trade that have benefited both the government and its people. 
In the reform era with prolonged critical conditions, the management of border issues cannot be done optimally (Sutisna et al., 2010). In the planning process, one of the border area management issues is that there has not been provided with an integrated and detailed development plan (Bappenas-BNPP, 2010). The border area is generally a lagging region with conditions prone to ideological, political, economic, and socio-cultural aspects, as well as defense and security. The most prominent phenomenon is the rampant of illegal logging, illegal trading, illegal trafficking, and the shifting of boundaries between countries. The border communities are generally poor and economically more oriented to neighboring countries - by conducting temporary or permanent migration with the main economic motive, as it occurs along the border area of West Kalimantan with Sarawak (Arifin 2011). The development policy model used by the government is irrelevant to the characteristics of the region such as bureaucratic culture that is still sectorial, the weakness of the border management authority, the inconsistency of technical policy with the border development paradigm, and the isolated geographical condition require extra-ordinary handling (Arifin 2013). Most of the border areas are relatively lagging and have not improved the welfare of the society and had gap with neighboring countries, this is due to the limited social economic facilities and infrastructure such as transportation facilities and infrastructure, telecommunications, settlements and the low quality of human resources that is imbalanced with the nature potentials (Gevisioner el al., 2013). Coastal communities are sometimes forgotten because the government policies are focused on development only. The welfare of fishermen is getting worse because of the decreasing of fishing targets, even over fishing, and the narrowing of fishing ground. On the other hand, the necessities of life are higher worsen by the destruction of the water environment and its ecosystem by human and natural disaster. Meanwhile, Kristiyanti (2016) also emphasized that communities around the coast are experiencing a downturn, because they have not been able to manage coastal resources optimally and they have limited knowledge about the use of resource development in the coastal areas, and do not know other effective and innovative ways to manage the coastal resources they produce.

Based on the background of the importance of development in the village, especially the border and coastal areas and the problems found, we are interested to create a model of community empowerment in the coastal border area based on ecotourism, precisely in Sebubus Village and Temajuk Village, Paloh Subdistrict, Sambas District, West Kalimantan.

\section{Method}

The study was conducted in 2018-2019 by identifying and analyzing community problems and potential, as well as carrying out the empowerment process thus the research method is relevant to used Participatory Rural Appraisal (PRA). Chambers (2007), Daniel and Nieldalina (2008) PRA is to provide effective support in the process of planning and implementation of development and community empowerment in a sustainable manner with an environmental perspective and based on local contexts in the process of identifying the potential and problems in his village. PRA as an approach that provides opportunities for village communities to share, improve and analyze knowledge about village living conditions, and make participatory plans, policies and actions. Implementation of PRA with activities (1) Mutual learning and sharing of experiences, (2) Involvement of all group members, (3) Outsiders as facilitators, (4) Application of the concept of triangulation (multidisciplinary PRA team, variation of techniques and diversity of resource persons). (5) Practical orientation and program sustainability. Data is collected through (1) Brainstorming to accommodate various aspirations, ideas, and suggestions. (2) Focus Group Discussion (FGD) to discuss a problem in a focused way; (3) Participatory Decision Making (PDM) to make decision (Huraerah 2011). The research location was determined in Sebubus Village and Temajuk Village, Paloh Subdistrict, Sambas District, West Kalimantan Province, considering that besides being a coastal area and border with Sarawak Malaysia, these villages are also areas that have great potential as a tourist village.

The study used purposive sampling to determine the informant or research subject selected on the consideration of the researcher that the informant or research subject can be useful to meet the needs and objectives of the study. The research informants as many as 35 people consisting of pioneer activists and empowerment activists, village government, community leaders, business groups, academics and tourist visitors. Data were analyzed through SWOT analysis with internal factors are: Strength and Weakness, and external factors are: Opportunities and Threats. (Rangkuti, 2014) and (Fatimah 2017).

\section{Results and Discussion}

Sambas District has a village on the western edge of Borneo island that is Temajuk Village which is formed in 2002 as the extension of Sebubus Village. It is located near Natuna Sea and northern territory which is directly adjacent to Sarawak State. Sambas District has an area of 6,395.70 km2 or 639,570 ha, about $20.12 \%$ of Paloh Subdistrict, is located in the northern part of the western coast of West Kalimantan province with a coastline of \pm $128,5 \mathrm{~km}$ and length of state border $\pm 97 \mathrm{~km}$. Based on the observation and analysis of monograph documentation 
of Temajuk Village in 2018 the uniqueness and attractiveness of Temajuk Village is due not only to its nature as a coastal and border area but it is also an area that has great potential as a tourist destination to become Tourism Village.

Important data as proof of interesting tourist attractions in the Sebubus and Temajuk Villages, namely types of tours offered in Sebubus Vilage are natural attractions of flora and fauna, mangrove tourism area, and turtle conservation, while in Temajuk Village it has tourist destinations such as Tugu Garuda Monument, Bajulang Stone, Gunung Pangi Waterfall, coral reef, Camar Bulan Quayside, and various beaches such as Surya, Batu Nenek, Maludin, Atong Bay, Pasir Plaik and Tanjung Datok. Based on data from tourism managers in Sebubus and Temajuk Villages every 2018-2019 holiday season between July and August, then December and January with 41,492 tourists going through Entikong by 33,246 (80.2\%) people and through Pontianak City 8,246 people (19.8\%). More visitors through the Entikong entrance because the distance to the Sebubus Village and Temajuk Village is closer to $250 \mathrm{~km}$ (5 hours 20 minutes) whereas if from Pontianak City $343 \mathrm{~km}$ (7 hours 21 minutes).

Community livelihoods in Temajuk Village are mainly fishermen, carpenters and construction workers, farmers and farm workers of rubber, coconut and pepper plantation and coastal tourism entrepreneurs. The level of education is generally as follows Elementary School (51.40\%), Junior High School (22.15\%), Senior High School (24.42\%) and Higher Education (2.03\%).

This study has several stages of activities, that are (1) a preliminary study on 2018 to 2019 about development and empowerment in the coastal border areas, namely (a) conducting a literature review of scientific journals and research findings, the study of mass media both print and online; (b) conducting discussions with practitioners and experts on the results of a literature review, the results can formulate problems, objectives, location and method of research; (c) preparing and submitting a research plan; (2) designing and implementing the research agenda on January 2018 such as (a) conducting discussions with research teams and colleagues especially key informants. (b) determining the instruments and research informants as well as the schedule of activities. (c) preparing research supplies and equipment. (3) Conducting research on February to April 2018 with the activities (a) opening access and asking for permission to the location of the research through key informants, (b) conducting in-depth interviews and dialogue with informants : empowerment activists, community leaders, village government especially village leaders, youth and people engaged in economic and tourism business groups and visitors. (c) conducting direct observation by visiting the location of economic activities and tourist attractions. (d) processing and analyzing documentation data and research results. (e) clarifiying and verifiying data with informants. (f) processing and analyzing data to create research reports and scientific articles.

\subsection{The Youth as Community Learning Activist of Ecotourism Empowerment in Coastal Border Society}

The community learning activist of empowerment are those who have the spirit, ideas, initiation, have access and can interact, eliminate, facilitate and mobilize the community to do the empowerment program. The empowerment communicator comes from the young as community learning activists who have high awareness and enthusiasm to advance Sebubus Village and Temajuk Village which before 2002 was still one of the hamlets of Sebubus Village. According to Marker (2009) community education can anticipate discriminatory education systems, dominance of the authorities, and decolonialisation, so that community education can maintain social capital and local wisdom of the community. Furthermore Marker (2015) historical education from the cultural realities of the community is very important to learn especially in coastal areas that have unique and interesting indigenous education and local wisdom without dependence on history books that have been established by the government. Munazah et al (2015) larning community is one of the learning models that can increase student activity in class. Students are required to be active and play a role to exchange knowledge in the learning community, making it easier for students to understand the material so that it has an impact on improving student learning outcomes. Asmin (2017) community learning could be a policy model in developing education programs of Corporate Social and Responsibility (CSR). The Community Learning policy model must involve the role of governments, scientists and non-governmental organizations to strengthen the implementation and development of education

The empowerment activists are involved in the research process using the PRA method, namely (1) Identifying and analyzing the problems, needs and potential of rural areas. (2) Formulation of the problem and setting priority problems (3) Identification of alternative solutions to the problem. (4) Selection of alternative problem solving in accordance with the ability of the community and available resources (5) Planning the application of ideas in the form of activity programs (6) Presentation of activity plans to stakeholders and the community in order to obtain input and improve more comprehensive program planning and implementation. (7) Implementation and organization of the community in accordance with the needs in the planned program and the level of community development. (8) Monitoring, assistance and (9) Evaluation and continuation of planned activities. 
The empowerment communicator was pioneered by Darmawan as chairman of the Kalilae group, as a youth activist that had college education and active in the organization. He has idealism, interpersonal communication skills, good access and cooperation with others, ideas and implementation of empowerment programs. He collaborated with Gustian, a youth activist from Temajuk, Chairman of the Camar Bulan Farmer Group and other youths who joined together with some community leaders who share the same passion and purpose for the progress of the village.

Youth activists as pioneer of empowerment is an important asset in rural development, in the midst of many young activists of community education leaving the village and the generation of farmers is decreasing because they think working in the city (urbanization) is more promising for their welfare. So that the awareness and high spirit of youth activists are good step to carry out development based on the potentials of the village both from agricultural resources, fisheries, and tourism. Because according to Gustina (2007) the younger generation has a lot of communication access that is used, because the curiosity of young people tend to be greater towards an information. Purwatiningsih (2012) stated that the thinking and participation of youth leaders usually generates new ideas (innovation) and give more color in the preparation of development planning in the village. Sudirtha (2017) community learning as lifelong education that can support formal education to improve the mindset, mental attitude, character and skills of human resources, especially the younger generation to be able to adapt to the challenges and developments.

Activist, pioneers of empowerment can be called opinion leaders who can influence and invite other youths as well as some community leaders who care about development in the village. Opinion leaders are characterized by higher formal education status, higher exposure media, more cosmopolitan and more experienced, empathic ability, greater social participation, and innovative in accepting and adopting new ideas (Nurudin 2005; Badri et al., 2008). Other empowerment actors come from community leaders who have long worked as farmers, fishermen and traders as well as former government officials who joined the village empowerment pioneers. These actors has experience and are well acquainted with the problems and potential of the village. Youth activists are a group of young as community learning activist who continue the work of their parents in the village as farmers, fishermen and do not continue their education to college. Young pioneers as empowerment communicators supported by community leaders and village youths are the driving force in the gradual development of the village, and can be referred to as community development drivers. According to Ife and Tosoriero (2008) community development is a process of facilitating the re-establishment of community structures as a new way to organize social life in meeting the needs, mobilizing resources, skills and wisdom of the community itself. Hasim and Remiswal (2009) stated community development as a strategy in social development by community members to work together to achieve the future of the community itself.

However, the community learning activist of empowerment as the opinion leader and community development is not fully supported by the village government both in the program and budget policy. So that the role of community development is still at the individual, family and small group stage and can not yet enter to the village government organizations and the whole community. As according to Suharto (2007) community development or community development is one of the unique approaches and methods of social work and involves handling problems from two levels: individuals, families, and groups (micro level), then organizations and communities (macro level). The focus of community development is essentially a planned social change strategy that is professionally designed to address problems or meet the needs at the community level.

The lack of support from the village government towards community development is due to the vast area of Sebubus village which reaches 326210 hectares and Temajuk village which has an area of 2,300 hectares. Development programs still tend to focus on government and administration expenditures and physical development, while less attention to empowerment programs. So that community participation, especially in making development planning is generally not running and people do not have the courage to convey their aspirations. People are more likely to get busy doing routine activity to earn a living by farming, becoming fisherman and farm laborer. The empowerment communicators, as the opinion leader and the community development actors have conducted a personal dialogue and group communication both informally and formally in the forum of village development planning on the importance of ecotourism empowerment program related to conservation and magrove tourism, honey farming (kelulut) in the magrove area and processing of mangrove fruit, but has not succeeded in becoming the main concern of the village development program. Although there are empowerment activities as well as assistance from the agricultural service and the marine and fishery agencies of the district, but it was only counseling and training activities, not mentoring and partnerships. So that the empowerment program has no sustainability and has no positive impact to the community. Whereas according to the Minister of Home Affairs Regulation No. 33 of 2009 on the guidance of ecotourism development in the region, 
in order to develop ecotourism in the region optimally it is necessary to have planning strategies, utilization, controlling, institutional strengthening, and community empowerment by taking into account social, economic, ecological, and involving stakeholders. Similarly, according to Flamin and Asnaryat (2013) and Haryanto (2014) the management of ecotourism requires cooperation between stakeholders both from the government, community and private parties.

There are other community learning activists outside the society, namely the World Wide Fund (WWF), an international non-governmental organization that carries out environmental mitigation, conservation and environmental restoration activities. WWF conducts research and empowerment on mangrove conservation and turtle conservation in Sebubus Village and Temajuk Village, Paloh Subdistrict. However, WWF has not been empowering local people to further improve their knowledge or skills and can not cooperate with local activists. WWF involves activists of empowerment and local communities only to support ceremonial activities and the publication of their work. By having stronger resources, programs and access WWF should be able to empower activists and local communities in order to improve their competence in community development. Ideally, empowerment communicators can synergize empowerment activist of youth and community leaders and WWF as civil society with local governments from village to district level, including with companies in Sambas in conducting joint programs to promote the potential of Sebubus Village and Temajuk Village.

The village and local governments make development policies by providing more open (democratic) opportunities for the community in this case community learning activist as civil society in giving aspiration and participation according to problems faced and potential owned. Government with related offices prioritize development programs through empowerment to be able to increase human resources in the form of spirit, awareness, knowledge, skills and independence as well as natural resources and economic resources of the community. The community learning activists can become facilitators, instructors, mentors and partners in empowerment programs both with the government and with the private sector. Furthermore, the private sector supports the policy and empowerment program that has been agreed by implementing the obligation to run the Corporate Social Responsibility (CSR) program. The obligations of the private sector to implement CSR are contained in Law No. 40 of 2007 on Limited Liability Companies. According to Article 1 (3) social and environmental responsibility is the company's commitment to participate in sustainable economic development in order to improve the quality of life and the environment that is beneficial for the company itself, the local community, and society in general. The synergy between government, civil society and the private sector in development is affirmed by Nugroho (2003), Sumarto (2004), Dwiyanto (2005) who stated that development is not only a government task but also requires various roles and other actors are civil society and private.loan that has finally given its trust and loan.

\subsection{The Empowerment of Community Learning Activist in Coastal Boarding}

The community learning activists as opinion leaders and community development actors have an important role in developing the potentials of Sebubus and Temajuk villages and synergizing them with government and private or corporate sectors. In the process of development and empowerment there is communication between civil society activists, government and private sector, stakeholders and experts, facilitators, instructors, extension workers, resource persons, volunteers and companions. According to Nurcholis et al. (2009), Mardikanto (2010), Buddenhagen and Baldwin (2011) there are actors who communicate in development to plan and implement programs, ie stakeholders. The communication function in the implementation of development becomes important in the success of development, especially for the stakeholders or the community learning activist to provide motivation, provide education and manage the community in a participative manner. The role of development actors involved in each planning process has an influence on development policy and can transform the public interest into the interests of the government and engage in the implementation process of the development program.

The community learning activists as development communicators in Sebubus and Temajuk villages have the idealism and passion to develop the potential of natural resources, especially conservation and mangrove tourism, coastal tourism and turtle breeding. Yhe community learning activists play a role in enhancing knowledge, motivation, experience and skills for the development of potential, especially conservation and coastal tourism, magrove forests, fisheries and agriculture. This is accomplished by the support of various government empowerment programs in the form of counseling, training and comparative studies from the Department of Marine Affairs and Fisheries Sambas District, Conservation Agency and Natural Data Sources (BKSD) and Development of Coastal Areas Tangguh (PKPT) from the Ministry of Marine Affairs and Fisheries during year 2015-2017. The results of the implementation of the empowerment program include a conservation tourism area under the name of Ecotourism Mangrove in Sebubus Village. There is also a honey farm where the nest is made around Mangrove Ecotourism area, processing of mangrove fruit that produce syrup products, jam, flour to make 
cake and chips. Other empowerment from the District Agricultural Service Agency in the form of counseling and training of organic fertilizer, cultivation of shallots, rice, pepper, horticultural agriculture, and training of rattan handicraft and comparative study of wood processing. Likewise the Atong bay tourism area also received attention and assistance from Sambas Regency government in the form of homestay made close to the beach as an attraction for tourists to visit and stay to enjoy the beauty of the beach. According to Salakory (2016) that ecotourism can be developed through the construction of mangrove facilities and infrastructure, increasing the capacity and competence of human resources, especially in mangrove management, designing ecotourism websites and coordinating with the government.

The participation of community learning activists in activities such as counseling, training and comparative studies outside the region is a form of good development communication network. Communication network according to Ramirez (2013), Cindoswari (2012) is a process of communication with the adoption of innovation obtained from outside communities to be model and applied in the community. Littlejohn and Foss (2008) mentioned that communication networks serve to manage information, build individual and group cohesiveness on similar interests and orientations, increase motivation and influence, exchange potential and resources. According to Eriyanto (2014) communications network is a linkage of individual relationships with interpersonal communication and can also with group communication that occurs in society.

The empowerment of community learning activist recognize the importance of access to development communication networks so that they utilize all existing communications media development, both conventional as interactional media in the form of seminars, discussions, workshops, counseling, audiences with government, training and comparative study or by utilizing new media such as internet through publication of both opinion papers and publication activities.

The effectiveness of empowerment communication is determined by the community learning activist and also by the empowerment medium that is used. According to Leeuwis (2006) media in communication empowerment consist of conventional communication media, interpersonal communication media and hybrid communication media or based on Information Communication and Technology (ICT). The community learning activists in implementing the village potential development program have not maximized the use of communication media as a source of information in Sebubus and Temajuk villages due to difficulties in obtaining or not being available. So the role of providing information, knowledge and increase the spirit to the public mostly through conventional media such as bulletin boards in the secretariat of empowerment organizations, mangrove ecotourism places and in the village office as well as the distribution of brochures. Media radio, newspapers and magazines and television is still difficult to access and used as a source of information empowerment.

Communication in empowerment through interactional media has been done by community learning activist of empowerment by always conducting informal dialogue activity either at home or in stall in discussing problem faced, plan of activity program to be implemented and proposed and evaluation activity. However, they still have problems conveying the idea of conservation and tourism development program and mangrove product in development communication through Forum of Village Development Planning (Musrenbangdes). Proposals at the neighborhood and hamlet levels can be drawn up, but when it comes to the Musrenbangdes stage it can not be fully accommodated, as programs and budgets for community and environmental empowerment are still marginalized by procurement and management programs in the areas of public administration and infrastructure. This is in line with previous research findings that Musrenbangdes is still dominated by the interests of local elites and prioritizes physical development and infrastructure rather than for the empowerment of the people's economy.

The results of the study indicate that there are still low levels of stakeholder access in every stage of communication forum activities such as the lack of citizen participation, openness of the forum, and the low intensity of dialogue activities. The government's response to community aspirations in Musrenbangdes is not yet maximal and is still far from what is needed by the community. The orientation of the development program still tends to the infrastructure development rather than the empowerment program (Mahmud 2007 \& Koswara 2010).

Therefore, community learning activists are more likely to seek opportunities and establish communication networks and cooperation with parties outside the village either to colleagues, non-governmental organizations and the central government. Community learning activists can be supported by academics from universities both with lecturers and students in research activities, work practices or internships, practicum and community service activities (KKN). Direct program support from both district, provincial and national governments can also be obtained as long as the empowerment of community learning activists proactively propose it. The government should also have priority development programs and budgets in border and coastal areas such as Sebubus Village and Temajuk Village. Because according to Amanah (2010) and Sutaat (2012) to overcome the gap that occurs 
between the condition of coastal communities with the conditions to be achieved there must be efforts through participatory, dialogical, and motivating development communication processes. Boonaree and Tuamsuk (2013) community education is the freedom of learning for the people according to their beliefs, potential and needs to develop themselves for the progress of village development

Communication in empowerment by community learning activist and government can also use media of Information Technology and Communication (ICT) which actually have been done by potential tourists by accessing information of tourism potency in Sebubus Village and Temajuk Village through website, blog and research journal According Zhu and Baylen (2006) learning communities with elements of pedagogy, technology and interactivity can be used as teaching methods to be used together in increasing interaction between students and helping them achieve course goals. There is a communication model of development through the use of media as pointed out by Sulaiman et al. (2016) that local governments and village governments can utilize conventional media such as notice boards and Internet-based information technology media in the form of websites to realize participatory, informative, transparent and accountable development programs to the public.

The attention of local and central government, especially the security officers, is only done when there is conflict in border area especially in Temajuk Village area which borders directly with Melano Malaysia. Conflict occurred due to the shifting marks or boundary marks of the territory, the seizure of land for palm and pepper plantations, and logging cases in the forest. The conflict had heated up and became a national issue during the border land dispute of Camar Bulan in 2011. The form of government attention at that time was still reactive and only limited to the security field, especially about the border area. Nevertheless, currently there has been a process of opening access road between Sebubus and Temajuk villages including ecotourism location, which began in 2017. According to Karsudi et al. (2010) in the development of ecotourism management should be able to create a conducive security situation both within and outside the tourist area. The developing community-based ecotourism concepts in addition to the social and economic dimensions of the village should also consider the political dimension.

In reality, attention to community empowerment programs has not been implemented optimally, comprehensively and sustainably. Supposedly, the empowerment program is designed and implemented with orientation on ecotourism development from motivation and cooperation to care for environment conservation, utilization of natural potency, especially coastal tourism and conservation of mangrove forest. Then by increasing the productivity of plantation products, fisheries and various types of food and beverages from the processing of mangrove fruit. In addition, by developing various game facilities around the beach such as venues by the beach voly sport, beach soccer, camping areas, outbound games of agility, sailboat and motorboad tours. Also by establishing and enhancing the role of economic and entrepreneurial institutions that can support the concept of ecotourism.

Ecotourism development in Sebubus and Temajuk villages can be pursued as a form of creating employment and prosperity for the community. According to the Minister of Home Affairs Regulation No. 33 of 2009 on guidelines for ecotourism development in the region, that ecotourism is a potential natural resources, environment, and uniqueness of nature and culture, which can be one of the leading sector areas that have not been developed optimally. Then in Article 1 it is mentioned ecotourism is a natural tourism activity in a responsible area by taking into account the elements of education, understanding, and support for natural resource conservation efforts, as well as increased incomes of local communities.

According to Karsudi et al. (2010) ecotourism development is run by spatial arrangement, game attraction management, promotion and marketing, then the establishment of regulation and management of ecotourism organization. Hijriyati and Mardiana (2014) stated that ecotourism influence socially can awaken the awareness to maintain and preserve the environment, then economically can create job opportunity and source of income of society. Aulia and Hakim (2017) affirm that the concept of ecotourism needs to be developed through the principles of natural resources and products produced by the community in a sustainable manner.

Nevertheless, the implementation of empowerment in Sebubus and Temajuk villages is only at the extension and training stage, but not yet sustainable, so it is less than optimal in the assistance and partnership on ecotourism. In addition, there is a weakness in the lack of synergy in managing ecotourism implemented by stakeholders as development actors either by the government, community learning activists of empowerment and private sectors, and the lack of utilization of communication media empowerment. Those things will complicate the development of ecotourism.

Researcher constructed the results of research by modeling the empowerment of community learning in coastal border, as in Figure 1. 


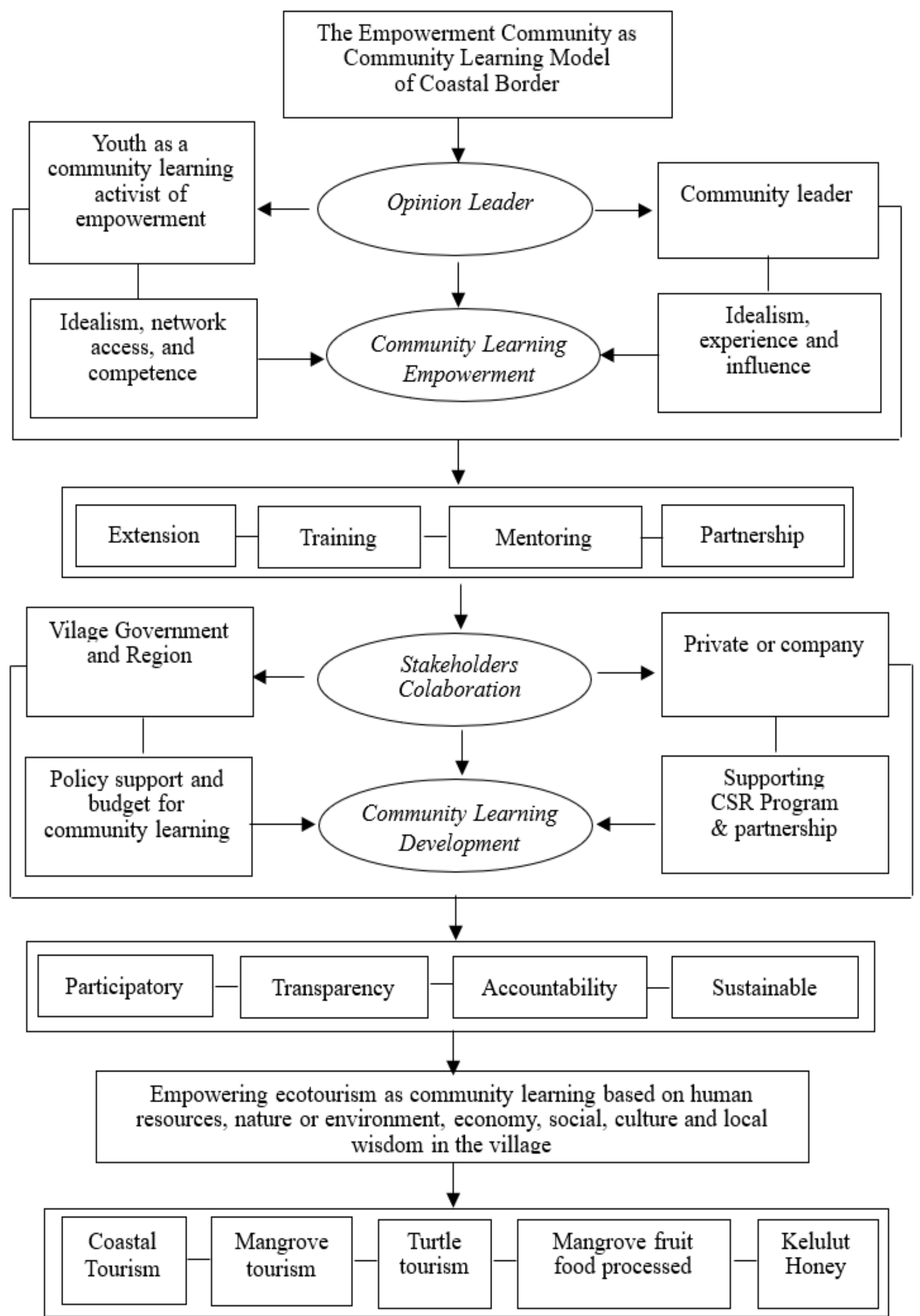

Figure 1. The Empowerment Model of Community Learning in Coastal Border 


\subsection{Community Empowerment Strategy of Coastal Border}

Based on the findings, we as researchers have made a strategy of empowering coastal border communities by using SWOT analysis as presented in Table 1

Table. 1 SWOT analysis of empowering coastal border communities

\begin{tabular}{|c|c|c|}
\hline & Strenght & Weakness \\
\hline Internal Factor & $\begin{array}{l}\sqrt{ } \text { Youths who are pioneers of community } \\
\text { learning activist have idealism and access to } \\
\text { develop ecotourism according to village } \\
\text { potential } \\
\sqrt{ } \text { Support from several community leaders, } \\
\text { business groups and youth who have the } \\
\text { awareness and passion to develop the } \\
\text { village potential. } \\
\sqrt{ } \text { Sebubus and Temajuk villages have a lot } \\
\text { of potential for ecotourism development } \\
\text { with community empowerment ie coastal } \\
\text { tourism, mangrove conservation forest and } \\
\text { turtle conservation along with mangrove } \\
\text { processing, Kelulut honey and fishery. } \\
\sqrt{ } \text { The people of Sebubus and Temajuk } \\
\text { village have high work ethic to earn a } \\
\text { living, have carpentry skills, and } \\
\text { accustomed to become plantation workers } \\
\text { especially oil palm, rubber and pepper and } \\
\text { to become fishermen. }\end{array}$ & $\begin{array}{l}\sqrt{ } \text { Uneven distribution of electricity service } \\
\text { facilities, good road access and } \\
\text { telecommunication and internet signals } \\
\sqrt{ } \text { Community learning activist programs } \\
\text { lack of support from village government } \\
\text { and local government especially in } \\
\text { determining development program in } \\
\text { village. } \\
\sqrt{ } \text { Development programs in the village are } \\
\text { still oriented to meet the needs of } \\
\text { administration and government } \\
\text { infrastructure, while neglecting } \\
\text { empowerment for ecotourism } \\
\sqrt{ } \text { the association of tourism actors has } \\
\text { little role in tourism development program } \\
\text { especially in Temajuk village. }\end{array}$ \\
\hline Opportunities & SO Strategy & WO Strategy \\
\hline $\begin{array}{l}\sqrt{ } \text { Many tourists come to visit Sebubus } \\
\text { Village and Temajuk Village to enjoy the } \\
\text { uniqueness, authenticity and beauty of the } \\
\text { beach. } \\
\sqrt{ } \text { Promotional media through the internet } \\
\text { about tourist attractions are accessible to } \\
\text { tourists. }\end{array}$ & $\begin{array}{l}\sqrt{ } \text { Conducting counseling programs, } \\
\text { training, mentoring and partnerships as } \\
\text { community learning for ecotourism } \\
\text { empowerment to develop all the potential of } \\
\text { mangrove and coastal forests, tourism } \\
\text { management, post-harvest management, } \\
\text { especially mangrove fruit. }\end{array}$ & $\begin{array}{l}\sqrt{ } \text { The high school administrators are } \\
\text { proactive in proposing more community } \\
\text { learning programs and scholarships for } \\
\text { students in Sebubus and Tamajuk villages } \\
\text { to continue their studies to universities }\end{array}$ \\
\hline $\begin{array}{l}\sqrt{ } \text { Road access to Sebubus and Temajuk } \\
\text { villages are in the process of development, } \\
\text { including the road from the Malaysian } \\
\text { Melano border which is closer to tourist sites. } \\
\sqrt{ } \text { Coastal conservation and coastal areas in } \\
\text { Sebubus and Temanjuk villages have been } \\
\text { the site of conservation activities of } \\
\text { international NGOs World Wide Fund } \\
\text { (WWF). }\end{array}$ & $\begin{array}{l}\sqrt{ } \text { Accelerate road construction and } \\
\text { ecotourism development with the } \\
\text { development of playgrounds, campsites, } \\
\text { beach games facilities, lodging and electric } \\
\text { lighting. } \\
\sqrt{ } \text { Training on advertising and promotion } \\
\text { techniques especially in social media for } \\
\text { promoting ecotourism and marketing of } \\
\text { community learning to developing } \\
\text { eco-empowerment and eco-tourism. }\end{array}$ & $\begin{array}{l}\sqrt{ } \text { Village and local governments provide } \\
\text { policy and budget support for community } \\
\text { learning as ecotourism empowerment } \\
\text { implementation programs and propose } \\
\text { improvements and development of } \\
\text { facilities at ecotourism sites } \\
\sqrt{ } \text { Village governments and activists of } \\
\text { empowerment and private sectorts can } \\
\text { work together for community learning of } \\
\text { ecotourism development. }\end{array}$ \\
\hline Threats & ST Strategy & WT Strategy \\
\hline $\begin{array}{l}\sqrt{ } \text { Many domestic migrants and foreigners } \\
\text { persuade the public to sell land near the } \\
\text { beach for a high price to be used as tourist } \\
\text { sites, which consequently the community } \\
\text { will lose their land assets. } \\
\sqrt{ } \text { The Communities are more dependent on } \\
\text { the need for economic fulfillment that is } \\
\text { cheaper, easier and closer. } \\
\sqrt{ } \text { Many people leave the village and pay less } \\
\text { attention to the potential of the village, }\end{array}$ & $\begin{array}{l}\sqrt{ } \text { Ecotourism of community learning } \\
\text { activists create awareness programs to } \\
\text { protect and conserve the natural } \\
\text { environment so as not to easily sale the land } \\
\text { and forest to overcome natural disasters. } \\
\sqrt{ } \text { Optimizing Corporate Social } \\
\text { Responsibility (CSR) funds from palm oil } \\
\text { companies for high education scholarships } \\
\text { and supporting community learning of } \\
\text { eco-empowerment programs }\end{array}$ & $\begin{array}{l}\sqrt{ } \text { Village and local governments raise } \\
\text { awareness of land ownership, especially } \\
\text { for economic and tourism businesses that } \\
\text { must prioritize the preservation, future and } \\
\text { welfare of rural communities learning. } \\
\sqrt{ } \text { Village and local governments provide } \\
\text { more open opportunities for community } \\
\text { participation in the planning and } \\
\text { development process. }\end{array}$ \\
\hline
\end{tabular}




\begin{tabular}{|c|c|c|}
\hline $\begin{array}{l}\text { preferring to seek work in Melano Malaysia } \\
\text { with higher wages. } \\
\sqrt{T h e} \text { potential for conflict and waning } \\
\text { nationalism due to social and economic } \\
\text { inequality at the border of Temajuk Village, } \\
\text { compared to Malaysia's Melano region, } \\
\text { which is more prosperous because it has the } \\
\text { attention of government and better } \\
\text { infrastructure. }\end{array}$ & $\begin{array}{l}\sqrt{ } \text { Create task force consisting village } \\
\text { government, community and security } \\
\text { apparatus to enforce public order and } \\
\text { security at border area especially for drug } \\
\text { and illegal logging cases. }\end{array}$ & $\begin{array}{l}\sqrt{ } \text { Village and local governments have } \\
\text { priority in development planning for } \\
\text { eco-empowerment programs to create and } \\
\text { improve community learning and } \\
\text { community welfare. }\end{array}$ \\
\hline
\end{tabular}

\section{Conclusion}

Temajuk village has many potential beaches and fish products, while Sebubus Village has potentials for mangrove forest, turtle breeding, processed drinks and food from mangrove fruit. So it requires the management of ecotourism that can create jobs and improve the welfare of the community through empowerment programs as community learning especially for the younger generation to become as community learning activists.

Road infrastructure from Sambas to Sebubus Village is relatively good, except after the Sekura River which is damaged as it is often passed by trucks carrying oil palm. While Temajuk Village still has problems of road infrastructure, electric lighting and telecommunication signal. Thus requiring local and central government policies to improve road and bridge infrastructure, electricity facilities and internet access for communication in supporting tourism access to Sebubus and Temajuk villages.

The empowerment of ecotourism has not been carried out continuously, yet it has not become a priority for village development and private partnership, so the community learning activist only get counseling, training, and comparative studies but are difficult to develop, due to the inadequate mentoring and partnership programs. The community empowerment program as community learning is carried out collaboratively and synergistically between the community, village and regional governments, universities, activists and the private sector.

The access of the border area from Melano Malaysia to the tourist sites of Temajuk village is closer, easier and better to travel, so people are still dependent on working as farmers, laborers and carpenters in Malaysia, including in terms of fulfilling the needs such as cooking oil, and rice. So that with the community empowerment program as community learning there will be no dependency and can create jobs, provide basic needs of the community and develop tourism potential as a village economic power.

Further research will carry out empowerment programs for young people as the implementation of community learning, especially students to increase motivation, care, knowledge, and skills about ecotourism management based on local wisdom and form young tourism awareness groups by involving empowerment activists as instructors and assistants.

\section{Acknowledgments}

We thank you for the opportunity given by Institute for Research and Community Service in University of Jenderal Soedirman, so that we can carry out research and The International Educational that have supported the publication of our research results. We also thank you for informants at the research location i.e community learning activist and village government who have participated in the research process.

\section{References}

Amanah, S. (2010). Peran Komunikasi Pembangunan dalam Pemberdayaan Masyarakat Pesisir. Jurnal Komunikasi Pembangunan, 8(1), 1-19, https://doi.org/10.29244/jurnalkmp.8.1.\%25p

Arifin, S. (2011). Migrasi Penduduk dan Implikasinya Terhadap Hankam di Wilayah Perbatasan Kalbar-Serawak. Jurnal Masalah-Masalah Hukum, 40(2), 220-227. https://doi.org/10.14710/mmh.40.2.2011.220-227

Arifin, S. (2013). Cross Border Approach Sebagai Alternatif Model Kebijakan Pembangunan Kawasan Perbatasan. Jurnal Hukum Ius Quia Iustum, 20(1), 37-58. https://doi.org/10.20885/iustum.vol20.iss1.art3

Asmin, F. (2017). The Model of Community Learning Center Development: A Case Study of PKBM Assolahiyah in West Java. Journal Ilmu Sosial Mamangan, 6(2), 61-70, https://doi.org/10.22202/mamangan.2312 
Aulia, A. N., \& Hakim, L. (2017). Pengembangan Potensi Ekowisata Sungai Pekalen Atas, Desa Ranu Gedang, Kecamatan Tiris, Kabupaten Probolinggo. Jurnal Wilayah dan Lingkungan, 5(3), 156-167, https://doi.org/10.14710/jwl.5.3.156-167

Badri, M., Hubeis, M., \& Maksum. (2008). Pemberdayaan Komunikasi Pemuka Pendapat dalam Penanganan Bencana Gempa Bumi Di Yogyakarta (Kasus Kabupaten Bantul). Jurnal Komunikasi Pembangunan, 6(1), 55-71. https://doi.org/10.29244/jurnalkmp.6.1.\%25p

Boonaree, C., \& Tuamsuk, K. (2013). Community Learning Resources Management Practices in Thai Buddhist Monasteries. Procedia-Social and Behavioral Sciences, 73, 175-180, https://doi.org/10.1016/j.sbspro.2013.02.038

Buddenhagen, R. W., \& Baldwin, J. R. (2011). Performing communicative functions in development projects: An exploratory study of development practices in Tanzania. International Journal of Intercultural Relations, 36(3), 418-429, https://doi.org /10.1016/j.ijintrel.2011.11.001

Chambers, R. (2007). From PRA to PLA and Pluralism: Practice and Theory. Brighton : Institute of Development Studies, University of Sussex.

Cindoswari, A. R. (2012). Jaringan Komunikasi dalam Penerapan Teknologi Produksi Ubi Kayu. Tesis. Bogor : Institut Pertanian Bogor.

Daniel M, Darmawati, \& Nieldalina (2008). Participatory Rural Appraisal (PRA): Pendekatan Efektif Mendukung Penerapan Penyuluhan Partisipatif dalam Upaya Percepatan Pembangunan Pertanian. Jakarta: Bumi Aksara.

Dwiyanto. A. (2005). Mewujudkan Good Governance Melalui Pelayanan Publik. Gadjah Mada University Press.

Eriyanto. (2014) Analisis Jaringan Komunikasi: Strategi Baru dalam Penelitian Ilmu Komunikasi dan Ilmu Sosial Lainnya. Jakarta: Prenada Media Group.

Fatimah, F. N. D. (2017). Teknik Analisis SWOT: Pedoman Menyusun Strategi yang Efektif dan Efisien serta Cara Pengelola Kekuatan dan Ancaman. Yogyakarta: Anak Hebat Indonesia.

Flamin, A., \& Asnaryati. (2013) Potensi Ekowisata dan Strategi Pengembangan Tahura Nipa-Nipa Kota Kendari Sulawesi Tenggara. Jurnal Penelitian Kehutanan Wallace, 2(2), 154-168, https://doi.org/10.18330/jwallacea.2013.vol2iss2pp154-168

Gevisioner., Bangun, R., \& Karyanti (2013). Strategi Pembangunan Berbasis Masyarakat di Kecamatan Perbatasan Negara di Provinsi Riau. Jurnal Bina Praja, 5(1), 53-62, https://doi.org/10.21787/jbp.05.2013.53-62

Gustina, A. (2007). Jaringan Komunikasi dan Peran Perempuan dalam Mempertahankan Budaya Rudat; Studi Pada Masyarakat Desa Negeri Katon, Kecamatan Negeri Katon, Lampung Selatan. Tesis. Bogor : Institut Pertanian Bogor.

Handoko, W., Sulaiman, A. I., \& Akbar, A. A. S. (2014). Participatory Communication in Development Process of Matenggeng Dams Cilacap District Central Java. Jurnal Penelitian Komunikasi, 17(2), 141-152, https://doi.org/10.20422/jpk.v17i2.13

Haryanto, J. T. (2014). Model Pengembangan Ekowisata dalam Mendukung Kemandirian Ekonomi Daerah Studi Kasus Provinsi DIY. Jurnal Kawistara. 4(3), 225-330. https://doi.org/10.22146/kawistara.6383

Hasim, \& Remiswal (2009). Community Development : Berbasis Ekosistem : Sebuah Alternatif Pengembangan Masyarakat, Jakarta : Diadit Media.

Hijriati, E., \& Mardiana, R. (2014). Pengaruh Ekowisata Berbasis Masyarakat terhadap Perubahan Kondisi Ekologi, Sosial dan Ekonomi di Kampung Batusuhunan, Sukabumi. https://doi.org/10.22500/sodality.v2i3.9422

Huraerah, A. (2011). Pengorganisasian dan Pengembangan Masyarakat: Model dan Strategi Pembangunan Berbasis Kerakyatan. Bandung: Humaniora.

Huruswati, I., Kurniasari, A., Purwanto, A. B., \& Sabeni, M. (2012). Evaluasi Program Pembangunan Kesejahteraan Sosial di Desa Perbatasan Kalimantan Barat, Jakarta: P3KS Press.

Ife, J., \& Tesoriero, F. (2008). Community Development: Community Based Alternatives in an Age of Globalization.. Australia (AU): Pearson Education.

Karsudi, Soekmadi, R., \& Kartodihardjo, H. (2010) .Strategi Pengembangan Ekowisata di Kabupaten Kepulauan 
Yapen Provinsi Papua. Jurnal Manajemen Hutan Tropika, 16(3), 148-154. https://doi.org/10.7226/jtfm.16.3.\%25p

Koswara. (2010). Strategi Penyelarasan Penyusunan APBD dengan RPJMD Untuk Meningkatkan Pembangunan Sarana dan Prasarana di Kota Bekasi. Tesis. Bogor: Institut Pertanian Bogor.

Kristiyanti, M. (2016). Pemberdayaan Masyarakat Pesisir Pantai melalui Pendekatan ICZM (Integrated Coastal Zoe Manajement). Prosiding. Seminar Nasional: Kajian Multi Disiplin Ilmu dalam Pengembangan IPTEKS untuk Mewujudkan Pembangunan Nasional Semesta Berencan (PNSB) sebagai Upaya Meningkatkan Daya Saing Global. Unisbank Semarang, 28 Juli 2016: 752-760.

Leeuwis, C. (2006). Communication for Rural Innovation : Rethingking Agricultural Extention. Oxford: Blackwell Publishing Ltd.

Littlejohn, S. W., \& Foss, K. A. (2008). Theories of Human Communication 9th. Singappre: Cengage Learning.

Mahmud., A. (2007). Model Komunikasi Pembangunan dalam Penyediaan Prasarana Perdesaan di Kawasan Pesisir Utara Jawa Tengah (Studi Kasus Desa Morodemak dan Purwosari Kabupaten Demak). Tesis. Semarang: Universitas Diponegoro.

Mardikanto, T. (2010). Komunikasi Pembangunan: Acuan Bagi Komunitas akademis, Praktisi, dan Peminat Komunikasi Pembangunan. Surakarta : UPT Penerbitan dan Pencetakan UNS Pr.

Marker, M. (2009). Indigenous resistance and racist schooling on the borders of empires: Coast Salish cultural survival. International Journal of the History of Education, 45(6), 757-772, https://doi.org/10.1080/00309230903335678

Marker, M. (2015). Borders and the borderless Coast Salish: decolonising historiographies of Indigenous schooling. Journal of the History of Education Society, 44(4), 480-502, https://doi.org/10.1080/0046760X.2015.1015626

Munazah, Y., Sugianto., \& Nugroho, S. E. (2015). Model Learning Community Berbasis Inkuiri Terbimbing untuk Meningkatkan Hasil Belajar Siswa dalam Pelajaran IPA FISIKA SMP. UPEJ Unnes Physics Education Journal, 4(3). https://doi.org/10.15294/upej.v4i3.9981

Nugroho, N. D. (2004). Reinventing Pembangunan. Jakarta: Gramedia Elex Media Komputendo.

Nurcholis, H., Milwan, T., \& Warsono, H. (2009). Perencanaan Partisipatif Pemerintah Daerah. Jakarta: Grasindo.

Nurudin. (2005). Sistem Komunikasi Indonesia. Jakarta: PT Raja Grafindo Persada.

Patriadi, H. B. (2010). Isu Perbatasan: Memudarnya 'Imagined State?, dalam Mengelola Perbatasan Indonesia Didunia Tanpa Batas, Isu, Permasalahan dan Pilihan Kebijakan. Yogyakarta: Graha Ilmu.

Purwatiningsih, S. D. (2012). Efektivitas Komunikasi Pembangunan pada Masyarakat Sekitar Hutan Konservasi Taman Nasional Gunung Halimun Salak. Disertasi. Bogor: Institut Pertanian Bogor.

Ramirez, A. (2013). The Influence of Social Networks on Agricultural Technology Adoption. Procedia - Social and Behavioral Sciences, 79, 101-116, https://doi.org/10.1016/j.sbspro.2013.05.059

Rangkuti, F. (2014). Analisis SWOT: Teknik Membedah Kasus Bisnis. Jakarta: Gramedia Pustaka Utama.

Salakory, R. A. J. B. (2016). Pengembangan Ekowisata Berbasis Masyarakat di Kepulauan Banda, Kabupaten Maluku Tengah. Jurnal Ilmu Pertanian Agrika, 10(1), 84-92. https://doi.org/10.31328/ja.v10i1.441

Salim, N. (2011). Analisis Pola Spasial Kemiskinan, Pembangunan Manusia/Sosial, dan Aktivitas Ekonomi, serta Keterkaitannya di Provinsi Kalimantan Barat. Tesis.. Institut Pertanian Bogor.

Sarosa, W. (2011). Kebijakan Pengelolaan Kawasan Perbatasan Indonesia. Jakarta: The Partnership for Governance Reform.

Sudirtha, I. G. (2017). Membangun Learning Community dan Peningkatan Kompetensi Melalui Lesson Study. Jurnal Pendidikan Indonesia, 6(1), 28-38. http://dx.doi.org/10.23887/jpi-undiksha.v6i1.8683

Suharto. (2007). Pekerjaan Sosial di Dunia Industri Memperkuat Tanggungjawab Sosial Perusahaan, Bandung: Refika Aditama.

Sulaiman, A. I,. Kuncoro, B., Sulistyoningsih., E. D., Nuraini, H., \& Djawahir, F. S. (2017). Pengembangan Agrowisata Berbasis Ketahanan Pangan Melalui Strategi Komunikasi Pemasaran di Desa. The Messenger. 9(1), 9-25, https://doi.org/10.26623/themessenger.v9i1.423 
Sulaiman, A. I., Lubis, D. P., Susanto, D., \& Purnaningsih, N. (2016). Merancang Media Informasi dalam Musyawarah Perencanaan Pembangunan Kota Banjar Provinsi Jawa Barat. Kawistara, 6(1), 93-106, https://doi.org/10.22146/kawistara.15504

Sumarto, H. S. (2004). Inovasi, Partisipasi dan Good Governance. Jakarta : Yayasan Obor Indonesia.

Sutaaat, (2012). Pemberdayaan Masyarakat Daerah Perbatasan Antar Negara. Sosiokonsepsia, 52(1), 52-71, https://doi.org/10.33007/ska.v17i1

Sutisna, S., Lokita, S., \& Sumaryo. (2010). Boundary Making Theory dan Pengelolaan Perbatasan di Indonesia: Dalam Mengelola Perbatasan Indonesia Didunia Tanpa Batas, Isu, Permasalahan dan Pilihan Kebijakan. Yogyakarta: Graha Ilmu.

Widiati, A. (2007). Kebijakan dan Strategi Penataan Ruang Kawasan Perbatasan Antarnegara di Provinsi Nusa Tenggara Timur. Jurnal Sains dan Teknologi Indonesia, 9(3), 110-119, http://dx.doi.org/10.29122/jsti.v9i3.779

Zhu, E., \& Baylen, D. M. (2006). From learning community to community learning: pedagogy, technology and interactivity. Journal: Educational Media International, 42(3), 251-268, https://doi.org/10.1080/09523980500161395

\section{Copyrights}

Copyright for this article is retained by the author(s), with first publication rights granted to the journal.

This is an open-access article distributed under the terms and conditions of the Creative Commons Attribution license (http://creativecommons.org/licenses/by/4.0/). 